\title{
Halifax doctor awarded \$1.4 million in damages
}

$\mathrm{F}$ ollowing a bitter, 14-year battle with her employer, Dr. Gabrielle Horne is celebrating a precedent-setting victory. A Nova Scotia Supreme Court jury has awarded the Halifax cardiologist $\$ 1.4$ million in damages - the highest amount ever awarded in Canadian history for loss of reputation and career. Horne will also receive more than $\$ 167000$ in legal fees.

"I'm thrilled," Horne said. "It has been a long time."

The legal saga began in 2002, when she was an assistant professor of medicine and biomedical engineering at Dalhousie University and staff cardiologist at the Queen Elizabeth II Health Sciences Centre (QEII). Horne allegedly refused to include a senior physician in her research team and its publications. In October that year, Horne's privileges were suspended by the Capital District Health Authority's board of directors amid accusations that she endangered patients, conducted unethical research and failed to be collegial.

A few weeks ago, on June 17, following a 33-day civil trial, a jury decided Horne's loss of privileges constituted bad faith or malice. Dr. Ken West, president of the District Medical Staff Association and a witness in the proceedings, called the situation "a classic case of workplace bullying."

Numerous issues and delays were identified during the trial. The Nova Scotia government, for example, has bylaws in place to ensure that when a physician's privileges are suddenly

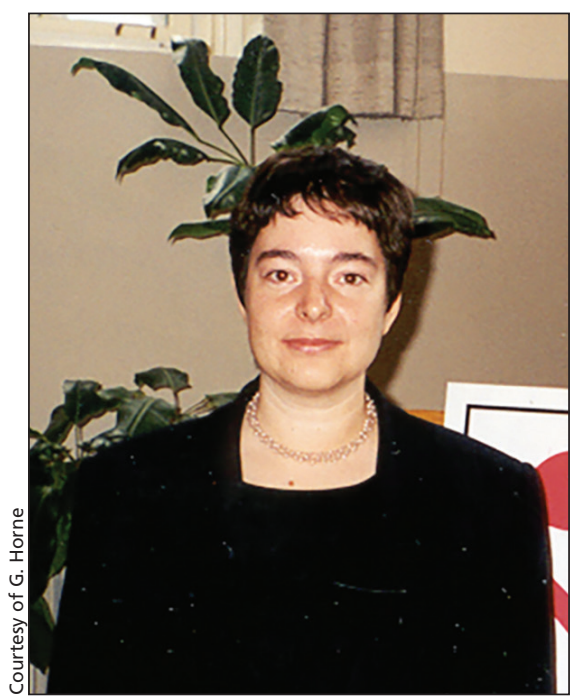

Cardiologist Gabrielle Horne's privileges were suspended in 2002, then reinstated four years later.

changed the review process takes no more than two weeks. For Horne, that process took four years.

When the Capital Health board of directors suddenly reinstated the cardiologist's privileges in 2006, it said their decision turned solely on a procedural issue. "The hospital wouldn't take any responsibility for what had happened. I was publicly smeared and still reporting to the same individuals," says Horne. "I really didn't have any choice but to pursue legal action."

Horne says her situation was "very extreme," but there are lessons in the decision for other health care centres across Canada, including ensuring a robust and fair investigation when claims are brought forward.
"Medicine is full of people with a lot of ambition and often big egos. When people make allegations, you cannot take them at face value," says Horne.

Personally, she adds, "it feels wonderful to have the scrutiny on those who made the allegations."

The legal saga has ended in victory for Horne, but the cardiologist is still grappling with uncertainty over her career. "I've not been able to get back to research," she says. "It's not clear what the future holds in that area." As a Dalhousie clinical research scholar, Horne once had $70 \%$ of her time protected for research, a key focus of which was the interaction between the heart's chambers and the septum.

One thing is certain: the support of Horne's colleagues has been invaluable. "That is what has made this survivable. There really is a lot of joy around me over the outcome of the trial."

For its part, the Nova Scotia Health Authority (Horne's current employer, which includes the former Capital Health District Health Authority) stated that "The events discussed occurred 14 years ago. It's not appropriate for us today to revisit the actions of previous organizations or administrators," the health authority said in a statement.

"We look forward to moving on from this matter with a continued focus on fostering an environment for leading health research and care," the authority added. - donalee Moulton, Halifax, NS

CMAJ 2016. DOI:10.1503/cmaj.109-5297 